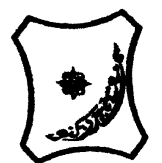

Bayero Journal of Pure and Applied Sciences, 8(1): 84 - 88

Received: January, 2015

Accepted: June, 2015

ISSN $2006-6996$

\title{
EFFECT OF IMAZAPYR TREATED MAIZE ON STRIGA INFESTATION AND TIME OF INTERCROPPING COWPEA IN SAMARU, NIGERIA
}

\author{
${ }^{*}$ Bello$^{1}$, T. T., Mohammed ${ }^{1}$, S. G., Kamara ${ }^{2}$, A. Y., Gashua ${ }^{3}$, A. G., Kurawa, ${ }^{4}$ I. A. and
} Adamu, ${ }^{5}$ U. A.

${ }^{1}$ Department of Agronomy, Bayero University, Kano, ${ }^{2}$ International Institute for Tropical Agriculture (IITA), Kano Station, ${ }^{3}$ Yobe State College of Agriculture, Gujba, ${ }^{4}$ Sa'adatu Rimi College of Education, Kano, ${ }^{5}$ Shelterbelt Research station, Kano, Forestry Research Institute of Nigeria.

*Correspondence author: ttbello05@yahoo.com +2348065883399

\begin{abstract}
Two field experiments were conducted at the research farm of Institute for Agricultural Research (IAR) Samaru, Zaria during the 2011 cropping season, with the aim of determining the effect of imazapyr treated maize on Striga infestation and time of intercropping cowpea in Samaru, northern guinea savannah of Nigeria. There were two sets of experiments: the first experiment consisted of Six (6) hybrids (AS1128-1, AS1128-2, AS1128-3, AS1128-4, AS1128-6 and AS1128-8) of imazapyr resistant (IR) maize seeds treated with imazapyr chemical and intercropped with cowpea at 2, 4 and 6 weeks after sowing (WAS) of maize. The second experiment consisted of the same Six (6) hybrids of IR maize seeds but untreated and also intercropped with cowpea at 2, 4 and 6 WAS of maize. The experiments were laid out in a split plot design with time of intercropping cowpea as main plot and hybrid maize varieties as sub plot, and replicated three times. The cowpea variety used for the trial was IT97K-499-35. Among the treated IR-maize hybrids, only AS1128-1, AS1128-2, AS1128-3 and AS1128-4 germinated while for the untreated, all the six hybrids germinated. The grain yields per hectare of all the treated maize hybrids did not significantly differed whereas grain yields per hectare of the untreated maize hybrids AS1128-1, AS1128-2, AS1128-3 and AS1128-4 were significantly higher than the hybrid AS1128-8. The treated IR maize hybrids exerted $100 \%$ control of Striga while the untreated supported Striga emergence. There was no visible damage symptoms observed on the cowpea intercropped with treated maize at all times of intercropping. It is therefore concluded that the IR-maize hybrids ASII28-1, ASII28-2, ASII28-3 and ASII28-4 should be used in the treated forms for the control of Striga. Moreover, the intercropping of cowpea with imazapyr treated maize can be carried out starting from 2 WAS of maize.
\end{abstract}

Key words: Intercropping, imazapyr resistant maize (IR-maize), cowpea, Striga.

\section{INTRODUCTION}

Maize (Zea mays L.) is one of the major food crops widely grown from the wet climate of the coast to the dry Sudan savannas of West and Central Africa. The yield potential of maize is particularly high in the savanna belt of this zone due to favourable growing conditions and reduced incidence of pests and diseases. Striga poses a serious threat to maize production in the high potential areas of the African savannas (Kim, 1991, Kling et al., 2000). Among the numerous species of Striga that are endemic to the savannas of Africa, Striga hermonthica (Del.) Benth is the most widespread and destructive species affecting cereals, with maize being the most susceptible (Kim, 1991, Berner et al. 1995). In maize croplands alone, Striga infests over 2.3 million hectares resulting in 1.6 million tons of grain loss worth US \$383 million annually (Woomer and Savala, 2007). It affects the livelihood of some 300 million people in Africa with 17 countries seriously affected and further 25 experiencing moderate damage (M'boob, 1989). In northern Nigeria, Berner et al. (1997) reported that over $85 \%$ of fields planted to maize and sorghum are infected with Striga.
One possible way to suppress parasitic weed emergence and prevent damage to the existing crop is by using herbicides that inhibit the activity of acetolactate synthase (ALS) (Garcia-Torres and Lopez-Granados, 1991; Abayo et al., 1996). These herbicides work by specifically inhibiting the biosynthesis of branched chain amino acids in the plant (Saari et al., 1994). Examples include imazapyr (Abayo et al., 1996), Sulfonylureas (Adu-Tutu and Drennan, 1991) or imazaquin (Berner et al., 1997). The herbicide is applied to maize that has target site resistance to the herbicide activity such that when it is coated, it absorbs some of the herbicide during germination and stimulates the germination of Striga which will then be killed before it can cause any damage. Maize with acetolactate synthase (ALS) inhibiting herbicides resistance was developed from tissue culture mutation (Newhouse et al., 1991). These herbicides may be applied to seed, such that low dosages in the range of $10-30 \mathrm{~g}$ active ingredient $\mathrm{ha}^{-1}$ are possible to control Striga effectively (Abayo et al., 1996; Berner et al., 1997). 
In Nigeria, most maize is grown in association with legumes particularly cowpea and there are concerns that the imazapyr chemical used to treat maize seeds may inhibit or reduce the germination and performance of cowpea since it is not resistant to imazapyr chemical. Due to these reasons, it becomes necessary to evaluate the performance of cowpea intercropped with imazapyr treated maize with a view to find the appropriate time of intercropping cowpea with treated maize.

\section{MATERIALS AND METHODS}

Field experiment was conducted during the 2011 rainy season at the Research farm of Institute for Agricultural Research (IAR), Samaru, Ahmadu Bello University, Zaria (Latitude $11^{0} 11^{1} \mathrm{~N}$ and Longitude $7^{0}$ $38^{1} \mathrm{E}, 686 \mathrm{~m}$ above sea level). There were two sets of experiments: In the first experiment, Six (6) hybrids of imazapyr resistant (IR) maize seeds (AS1128-1, AS1128-2, AS1128-3, AS1128-4, AS1128-6 and AS1128-8) treated with imazapyr chemical intercropped with cowpea (IT97K-499-35) at 2, 4 and 6 weeks after sowing (WAS) of maize. The second experiment consisted of the same Six (6) hybrids of IR maize seeds but untreated and also intercropped with cowpea at 2, 4 and 6 WAS of maize. The experiments were laid out in split plot design with time of intercropping cowpea as main plot and hybrid maize varieties as sub plot, and replicated three times.

The field was harrowed and made into ridges of about $75 \mathrm{~cm}$ apart, the plots were then laid out according to treatments. The Striga-Sand mixture was made at a ratio of $10 \mathrm{~g}$ to $1000 \mathrm{~g}$ of Striga and sand respectively, each planting hole received $10 \mathrm{~g}$ of the mixture (inoculum) at planting. Three maize seeds were carefully placed on the Striga inoculum in the planting hole and covered gently at an intra row spacing of $50 \mathrm{~cm}$ and later thinned to one plant per hill at 2 weeks after sowing (WAS). Also, three cowpea seeds were planted between two maize plants which is equivalent to $50 \mathrm{~cm}$ between two stands of cowpea at 2, 4 and 6 WAS of the maize seeds, and later thinned to one plant per hill. The fertilizer was band applied at the rate of $30 \mathrm{~kg} / \mathrm{ha}$ each of $\mathrm{N}, \mathrm{P}_{2} \mathrm{O}_{5}$ and $\mathrm{K}_{2} \mathrm{O}$ at planting and an additional $30 \mathrm{kgN} / \mathrm{ha}$ was applied inform of urea $(46 \%)$ as top dressing at 5 WAS of the maize crop. The number of emerged Striga were counted from the net plot at 10 and 12 weeks after sowing (WAS) and the visual damage symptoms of Striga were observed and rated at 10 and 12 WAS of maize by using a scale of 1 to 9 , where $1=$ no visible symptoms and $9=$ all leaves completely scorched resulting in premature death as described by Kim et al., (2002). Data were also taken on grain yield and 100 seed weight for both the maize and cowpea plants. The data generated were subjected to analysis of variance (ANOVA) as described by Snedecor and Cochran (1967) using GenStat (GenStat, 2011).

\section{RESULTS AND DISCUSSION}

\section{Number of emerged Striga}

Table 1 shows that the Striga did not emerge at 10 and 12 WAS in the treated maize hybrids, whereas for the untreated, hybrids ASII28-6 recorded higher number of emerged Striga with 38 and 56 Striga plants at 10 and 12 WAS, respectively. These were closely followed by the hybrid AS1128-8 that supported 24 and 30 Striga plants in the respective sampling period. The remaining hybrids supported insignificant number of Striga plants that ranged from 5 to 7 at 10 WAS, and 8 to 10 at 12 WAS. The absence of Striga on treated maize hybrids could be attributed to the chemical protection of the seeds by imazapyr, which is in agreement with the findings of Berner et al. (1997) and Kanampiu et al. (2009) in their separate studies, which demonstrated that IRmaize seed dressed with imazapyr has been successfully used in the control of Striga plant.

\section{Striga damage rating}

There were no visible Striga damage symptoms on the treated hybrids at 10 WAS, but at 12 WAS, Striga damage symptoms were observed in which hybrids AS1128-1 and AS1128-4 recorded significantly higher Striga damage scores than the other hybrids (Table 1). Among the untreated hybrids, the AS1128-8 showed higher Striga damage score (4.2) than the other hybrids at 10 WAS. At 12 WAS the hybrid AS1128-8 recorded higher damage score (6.4) than the other hybrids followed by AS1128-6 (4.3). The hybrids AS1128-1, AS1128-2, AS1128-3 and AS11284 had statistically similar and lower Striga damage scores. Kanampiu et al. (2001) demonstrated that, imazapyr coated maize seeds exude germination stimulants into the rhizosphere thereby inducing germination of Striga seeds, which were consequently killed. Also, the relatively less Striga damage symptoms observed on the untreated IR-maize was in agreement with the findings of Menkir et al. (2009) which revealed that hybrids formed from selected IRmaize inbred lines with field resistance to $S$. hermonthica sustained less damage symptoms under S. hermonthica infestation and supported fewer emerged parasites than the susceptible hybrid check. 100 kernel weight (g)

Table 2 shows that the treated hybrid AS1128-1 recorded significantly higher 100 kernel weight which was statistically at par with AS1128-2 while hybrid AS1128-3 recorded the least 100 kernel weight. Among the untreated maize, hybrid AS1128-2 recorded highest 100 kernel weight followed by AS1128-1 and AS1128-6. The hybrid AS1128-8 recorded the lowest 100 kernel weight. Arnon (1972) reported that different cultivars grown under the same conditions may have differences in their performance due to genetic make up.

\section{Kernel yield $\left(\mathrm{kgha}^{-1}\right)$}

There were no significant differences among the kernel yield per hectare of the treated hybrid maize (Table 2). Among the untreated hybrids however, AS1128-1, AS1128-2, AS1128-3 and AS1128-4 recorded significantly higher kernel yield per hectare with yield ranged from $2613.1 \mathrm{~kg}$ for hybrid AS1128-1 to $2717.8 \mathrm{~kg}$ for hybrid AS1128-2. The hybrid AS11288 recorded the least $(1474.8 \mathrm{~kg})$ kernel yield per hectare. 
This could be due to differences in the ability of the hybrids to exploit resources especially water and nutrients (Falconer, 1989). Also, the kernel yield performance of the treated maize is in agreement with the findings of Kanampiu et al. (2001) who observed that treated IR-maize gave higher kernel yield than the untreated ones.

100 grain weight and grain yield of intercropped cowpea

Table 3 shows that the cowpea intercropped with treated maize has germinated and produced successfully, this was in agreement with the findings of CIMMYT (2008) which reported that, the low dose herbicide seed dressing on IR maize will control Striga without having severe damage on the crop intercropped at $10 \mathrm{~cm}$ or more from the maize hills. The cowpea intercropped at 4 and 6 WAS were at par in both experiments and produced significantly higher 100 grain weight than intercropping at 2 WAS. A statistically similar cowpea grain yield was produced when the cowpea was intercropped with treated maize hybrid, whereas the cowpea intercropped with untreated maize at 2 WAS produced significantly higher grain yield than other times of intercropping. Generally, the cowpea intercropped at 2 WAS produced highest grain yield in both treated and untreated maize. This was probably due to the fact that introducing cowpea earlier may allow the crop to make full use of soil moisture during the cropping season and also to utilize solar radiation more efficiently since it was introduced at the early stage of maize growth. Dhital et al. (1997) reported that early planting of cowpea resulted in higher number of pods per plant and number of seeds per pod.

\section{Conclusion}

The findings of this study revealed that, among the treated IR-maize hybrids planted only ASII28-1, ASII28-2, ASII28-3 and ASII28-4 germinated and performed better than the untreated hybrids. Also the untreated IR-maize hybrids evaluated sustained relatively less yield loss due to their resistance to Striga except ASII28-8 which recorded a poor performance.

The study showed that the IR-maize hybrid ASII28-1, ASII28-2, ASII28-3 and ASII28-4 in their treated form can be used to achieve a maximum Striga suppression. Also, these findings clearly showed that intercropping of cowpea with imazapyr treated maize is feasible starting from 2 WAS.

Table 1: Effect of time of intercropping and IR-maize hybrids on numbers of emerged Striga and Striga damage rating at 10 and 12 WAS of maize at Samaru, 2011.

\begin{tabular}{|c|c|c|c|c|c|c|c|c|}
\hline \multirow[b]{3}{*}{ Treatment } & \multicolumn{4}{|c|}{ numbers of emerged Striga } & \multicolumn{4}{|c|}{ Striga damage rating } \\
\hline & \multicolumn{2}{|c|}{10 WAS } & \multicolumn{2}{|c|}{12 WAS } & \multicolumn{2}{|c|}{10 WAS } & \multicolumn{2}{|c|}{12 WAS } \\
\hline & treated & untreated & treated & untreated & treated & untreated & treated & untreated \\
\hline \multicolumn{9}{|c|}{ Time of intercropping (T) (WAS) } \\
\hline 2 & 0.0 & 10.2 & 0.0 & 15.1 & 1.0 & 2.5 & 1.8 & 3.7 \\
\hline 4 & 0.0 & 21.8 & 0.0 & 32.2 & 1.0 & 2.6 & 1.3 & 3.6 \\
\hline 6 & 0.0 & 10.4 & 0.0 & 13.1 & 1.0 & 2.1 & 1.5 & 2.8 \\
\hline SED & 0.00 & 1.88 & 0.00 & 4.79 & 0.00 & 0.31 & 0.23 & 0.21 \\
\hline \multicolumn{9}{|c|}{ Hybrids maize (H) } \\
\hline ASII28-1 & 0.0 & $7.3 b$ & 0.0 & $10.2 b$ & 1.0 & $2.0 \mathrm{bcd}$ & $1.8 \mathrm{a}$ & $2.6 \mathrm{c}$ \\
\hline ASII28-2 & 0.0 & $4.8 b$ & 0.0 & $7.8 \mathrm{~b}$ & 1.0 & $1.4 \mathrm{~d}$ & $1.1 \mathrm{c}$ & $2.0 \mathrm{c}$ \\
\hline ASII28-3 & 0.0 & $5.1 b$ & 0.0 & $7.9 \mathrm{~b}$ & 1.0 & $2.2 b c$ & $1.4 b$ & $2.7 c$ \\
\hline ASII28-4 & 0.0 & $5.8 b$ & 0.0 & $9.0 \mathrm{~b}$ & 1.0 & $1.9 \mathrm{~cd}$ & $1.9 a$ & $2.2 \mathrm{c}$ \\
\hline ASII28-6 & - & $37.8 a$ & - & $56.0 \mathrm{a}$ & - & $2.6 \mathrm{~b}$ & - & $4.3 b$ \\
\hline ASII28-8 & - & 24.1ab & - & $29.8 \mathrm{ab}$ & - & $4.2 a$ & - & $6.4 a$ \\
\hline SED & 0.00 & 6.78 & 0.00 & 16.36 & 0.00 & 0.44 & 0.16 & 0.52 \\
\hline \multicolumn{9}{|c|}{ Interaction } \\
\hline $\mathrm{T} \times \mathrm{H}$ & NS & NS & NS & NS & NS & NS & NS & NS \\
\hline
\end{tabular}

Means followed by the same letter(s) within a column are not significantly different at $5 \%$ level of probability using DMRT. - not germinated, NS = not significant. 
Table 2: Effect of times of intercropping and IR-maize hybrids on 100 kernel weight and kernel yield of maize at Samaru, 2011.

\begin{tabular}{|c|c|c|c|c|}
\hline \multirow[b]{2}{*}{ Treatment } & \multicolumn{2}{|c|}{100 kernel weight $(\mathrm{g})$} & \multicolumn{2}{|c|}{ Kernel yield $\left(\mathrm{kgha}^{-1}\right)$} \\
\hline & treated & untreated & treated & untreated \\
\hline \multicolumn{5}{|c|}{ Time of intercropping (T) (WAS) } \\
\hline 2 & 24.7 & 23.3 & 2204.2 & 2231.0 \\
\hline 4 & 25.8 & 22.4 & 2953.7 & 2378.0 \\
\hline 6 & 27.5 & 24.9 & 2621.2 & 2567.0 \\
\hline SED & 1.38 & 0.91 & 2.3 .36 & 205.7 \\
\hline \multicolumn{5}{|c|}{ Hybrid maize (H) } \\
\hline ASII28-1 & $28.3 a$ & $25.4 a b$ & 2690.6 & 2613.0a \\
\hline ASII28-2 & 27.3ab & $26.5 a$ & 2672.7 & 2718.0a \\
\hline ASII28-3 & 23.2c & $23.2 b$ & 2596.5 & 2686.0a \\
\hline ASII28-4 & $25.0 \mathrm{bc}$ & $23.4 b$ & 2412.5 & $2688.0 \mathrm{a}$ \\
\hline ASII28-6 & - & $24.6 a b$ & - & $2172.0 \mathrm{~b}$ \\
\hline ASII28-8 & - & $18.0 \mathrm{c}$ & - & 1475.0c \\
\hline SED & 1.30 & 1.46 & 173.62 & 243.5 \\
\hline \multicolumn{5}{|c|}{ Interaction } \\
\hline $\mathrm{T} \times \mathrm{H}$ & NS & NS & NS & NS \\
\hline
\end{tabular}

Means followed by the same letter(s) within a column are not significantly different at $5 \%$ level of probability using DMRT. - not germinated, NS = not significant.

Table 3: Influence of time of intercropping cowpea and IR-maize hybrids on 100 grain weight and grain yield of cowpea at Samaru, 2011.

\begin{tabular}{|c|c|c|c|c|}
\hline \multirow[b]{2}{*}{ Treatment } & \multicolumn{2}{|c|}{100 grain weight $(\mathrm{g})$} & \multicolumn{2}{|c|}{ Grain yield $\left(\mathrm{kgha}^{-1}\right)$} \\
\hline & treated & untreated & treated & untreated \\
\hline \multicolumn{5}{|c|}{ Time of intercropping (T) (WAS) } \\
\hline 2 & $13.4 b$ & $13.6 b$ & 364.3 & $199.4 a$ \\
\hline 4 & $17.8 a$ & $16.4 a$ & 364.2 & $123.2 b$ \\
\hline 6 & $18.1 a$ & $16.2 a$ & 258.1 & $84.2 c$ \\
\hline SED & 0.89 & 0.76 & 106.1 & 26.06 \\
\hline \multicolumn{5}{|c|}{ Hybrid maize (H) } \\
\hline ASII28-1 & 15.5 & 15.6 & $272.0 b c$ & 109.1 \\
\hline ASII28-2 & 17.5 & 15.5 & $221.0 \mathrm{c}$ & 114.4 \\
\hline ASII28-3 & 16.8 & 15.0 & $250.0 c$ & 109.0 \\
\hline ASII28-4 & 15.9 & 15.6 & $268.0 b c$ & 133.0 \\
\hline ASII28-6 & 16.3 & 14.0 & 372.0ab & 139.4 \\
\hline ASII28-8 & 16.7 & 16.3 & 398.0a & 141.1 \\
\hline SED & 1.03 & 1.02 & 95.9 & 36.07 \\
\hline \multicolumn{5}{|c|}{ Interaction } \\
\hline $\mathrm{T} \times \mathrm{H}$ & NS & NS & NS & NS \\
\hline
\end{tabular}

Means followed by the same letter within a column are not significantly different at $5 \%$ level of probability using DMRT. - not germinated, NS = not significant.

\section{REFERENCES}

Abayo, G. O., Ransom, J. K., Gressel, J., Odhiambo, G. G. (1996). Striga hermonthica control with acetolactate synthase-inhibiting herbicides seed-dressed on maize with target site resistance. In: Toreno, M.T., Cubero, J.I., Berner, D., Joel, D.M., Musselman, L., Parker, C. (eds.) Advances in Parasitic Weeds Plant Research. Junta De Andelucia. Consejeria da Agriculturally Pesca. Cordova, Spain, pp. 762-768.

Adu-Tutu, K.O. and Drennan, D.S.H. (1991). Effect of Sulfonyurea Herbicides on Striga. In: Ransom J.K., Musselman A.D., Worsham Parker C. (eds) Proceedings of the Fifth
International Symposium of Parasitic Weeds. Nairobi: CIMMYT, pp. 361-371.

Arnon, I. (1972). Crop Production in Dry Region. Leonard Hill Books, 158 Buckingham Palace Road, London.

Berner, D.K., Ikie, F.O. and Green, J.M. (1997). ALSInibiting Herbicide Seed Treatments Control Striga hermonthica in ALS-Modified Corn (Zea mays). Weed Technology. 11: 704-707.

Berner, D.K., Kling, J. G., Singh, B.B. (1995) Striga Research and Control: A Perspective from Africa. Plant Diseases, 79: 652-660.

CIMMYT, (2008). Striga Weed Control with herbicide coated maize seed from http://www.cimmyt.org/research/maize/resu Its/control.pdf. 
Dhital, B. K., Hardind, A. H. and Subedi, M. (1997) Effect of planting date on phenology, yield components and grain yield of determinate cowpea varieties in the low hill of Nepal and electronic networking for sustainable development in Nepal.

Falconer, D. S. (1989) Introduction to quantitative genetics, $3^{\text {rd }}$ edition. Longman Scientific and Technical Essex England.

Garcia-Torres, L. and Lopez-Granados, F. (1991). Control of bromerape (Orobanche crenata Forsk.) in broad bean (Vicia faba L.) with imadazolines and other herbicides. Weed Res. 31: 227-235.

GenStat (2011). Release 10.3DE. VSN International, 5 The Waterhouse, Waterhouse Street, Hemel Hempstead, Hertfordshire HP1 1ES, UK.

Kanampiu, F. K., Karaya, H., Burnet, M. and Gressel, J. (2009) Needs for and effectiveness of slow release herbicide seed treatment Striga control formulations for protection against early season crop phytotoxicity. Journal of Crop Protection, 28(10): 845-853.

Kanampiu, F. K., Mbogo, P and Massawe, C. (2001) Multi-Location Testing of HerbicideResistant Maize to Control Striga. Seventh Eastern and Southern Africa Regional Maize Conference $11^{\text {th }}-15^{\text {th }}$ February, 2001. pp. 169 - 172.

Kim, S. K (1991) Breeding maize for Striga tolerance and development of field infestation technique In; S.K Kim (ed) combating Striga in Africa. Proceeding of the international workshop organized by IITA, KRISAT and IDRC, August 22-24 1998. IITA Ibadan Nigeria.
Kling, J. G., Fajemisin, J. M., Badu-Apraku, B., Diallo, A., Menkir, A. and Melake-Berhan, A. (2000) Striga resistance breeding in maize. In: B.I.G. Haussmann, D.E. Hess, M.L. Koyama, L. Grivet, H.F.W. Rattunde, and H.H. Geiger (eds), Breeding for Striga resistance in Cereals, pp. 103-118. Proceedings of a workshop held at IITA, Ibadan, Nigeria. 1620 August 1999. Margraf Verlag, Weikersheim, Germany.

M'boob, S. S. (1989) A Regional Programme for West and Central Africa. P. 190 - 194. In T. O. Robson and H. R. Broad (eds.) Striga improved management in Africa. Proceedings of the FAO/OAU. All African Government Consultation on Striga Control, Marova. 20-24 October, 1986. Marova, Cameroon.

Menkir, A., Chikoye, D. and Lum, F. (2009) Incorporating an herbicide resistance gene into tropical maize with inherent polygenic resistance to control Striga hermonthica (Del.) Benth. Plant Breeding, 129, 385-392.

Newhouse, K.E., Singh, B., Shaner, D. and Stidham, M. (1991). Mutations in maize (Zea mays L.) conferring resistance to imidazolinone herbicides. Theor. Appl. Genet. 83: 65-70.

Saari, L.L, Cotterman C, Thill D.C. (1994). Resistance to acetolactatesynthase-inhibitor herbicides. In: Powles S.B., Holtum JA (eds). Herbicide Resistance in Plants: Biol. Biochem. Chelsea M1: Lewis, pp. 80-139.

Snedecor, G. W. and Cochran, W. G. (1967) Statistical methods sixth edition: Iowa University, Press, Iowa, USA 606 - 607.

Woomer, P. L. and Savala, C. N. (2007) Striga Management through Herbicide Resistance: A Public-Private Partnership in Action. AAAE Conference Proceedings 489-496. 